University of South Carolina

Scholar Commons

Faculty Publications

Law School

7-2014

\title{
Pink Franklin v. South Carolina: The NAACP's First Case
}

W. Lewis Burke

University of South Carolina - Columbia, wlburkej@law.sc.edu

Follow this and additional works at: https://scholarcommons.sc.edu/law_facpub

Part of the Civil Rights and Discrimination Commons

Recommended Citation

W. Lewis Burke, Pink Franklin v. South Carolina: The NAACP's First Case, 54 Am. J. of Legal History 265 (2014).

This Article is brought to you by the Law School at Scholar Commons. It has been accepted for inclusion in Faculty Publications by an authorized administrator of Scholar Commons. For more information, please contact digres@mailbox.sc.edu. 


\title{
Pink Franklin v. South Carolina: The NAACP's First Case
}

\author{
by W. LEWIS BURKE*
}

"It causes mobs to formulate, to come and go at will, At morning, evening noon or night, a Negro man to kill, It brings injustice to the courts when negro men are tried, It wrings the ballot from his hands-a thousand wrongs beside. ${ }^{1 "}$

\section{INTRODUCTION}

In 1907, Lizelia Moorer published a volume of poetry entitled "Prejudice Unveiled." Mrs. Moorer was a witness to the injustices of Jim Crow South Carolina, the wife of a lawyer who fought racial prejudice in a landmark trial, and a poet who foretold the story that came to be known as the Pink Franklin case. Like Lizelia Moorer's poetry, Pink Franklin's murder trial and subsequent appeal are little known. In 2009, the National Association for the Advancement of Colored People, the NAACP celebrated its 100th Anniversary, but its official on-line history for that occasion did not even mention Franklin v. South Carolina, the first case ever undertaken by the NAACP. ${ }^{2}$ In 2004 when the fiftieth anniversary of Brown v. Board of Education was commemorated, numerous scholars debated the meaning of the NAACP's most important case. ${ }^{3}$ The Brown decision

* The author is Professor of Law at the University of South Carolina School of Law. He wishes to thank Dr. Michael Mounter, Jack Cohoon, Dr. Patricia Sullivan, $\mathrm{O}^{\prime} \mathrm{Neal}$ Smalls, and Anne Burke for their assistance and advice. Special appreciation must be expressed to my dear friends, Cindie and Mike Gillis who through their skill as genealogists discovered what happened to Pink Franklin after 1918.

1 "Prejudice" in Lizelia Augusta Jenkins Moorer, Prejudice Unveiled at 7 (Boston: Roxburgh Pub. Co. 1907) reprinted in Joan R. Sherman, ED., Collected Black Women's POETRY (New York: Oxford University Press 1988).

${ }^{2}$ See Webpage for the NAACP Centennial Celebration at http://www.naacp.org/ about/history/index.htm (last visited March 16, 2010).

${ }^{3}$ Compare Michael Klarman, From Jim Crow to Civil Rights (Oxford: Oxford University Press 2004) and Paul Finkleman, "Civil Rights in Historical Context: In Defense of Brown," 118 Harvard Law Review 973 (2005). 
and the NAACP's strategy of attacking segregated schools were chronicled and critiqued in numerous books and articles. ${ }^{4}$ Other important cases such as the white primary cases and the Ossian Sweet case have also received book length treatments. ${ }^{5}$ But the Pink Franklin case has received either passing references in the histories of the NAACP ${ }^{6}$ or worse inaccurate renditions in some law reviews. ${ }^{7}$

Founded in February of 1909, the NAACP was first a fledgling group named the "National Negro Committee." Its original goals was to secure for black Americans the rights promised by the Fourteenth and Fifteenth Amendments to the U.S. Constitution. ${ }^{8}$ The biracial group included such people as Ida B. Welles-Barnett, Mary White Ovington, W.E.B. DuBois, Henry Moskovitz, William English Walling, Oswald Villard, and John E. Milholland. Welles-Barnett was the spokesperson of the anti-lynching movement. Ovington was active in the settlement movement. Walling was a wealthy Southerner who had become a socialist and a labor activist. Villard was a newspaperman with abolitionist roots. An academic, DuBois was considered the leading intellectual in the African American community. Milholland was a wealthy New York reformer with a strong interest in civil rights. Their backgrounds and activities led them to the NAACP and ultimately to the Pink Franklin case.

In 1903 Milholland founded the Constitution League to protect the civil rights of black Americans. ${ }^{9}$ The organization was eventually

${ }^{4}$ RiCHARd KLUGer, Simple Justice (New York: Alfred A. Knopf 1976), Gerald Rosensberg, Hollow Hope (Chicago: U. of Chicago Press 1991); and Derrick Bell, Silent Covenants (London: Oxford Univ. Press 2004).

${ }^{5}$ Darlene Clark Hine, Black Victory: The Rise and Fall of the White Primary in Texas (London: University of Mo. Press 2003) and KeVIN Boyle, ARC Of Justice (New York: Henry Holt and Co. 2005).

${ }^{6}$ See Patricia Suluivan, Lift Every Voice: The NAACP and the Making of the Civil rights Movement 18 (New York: The New Press 2009); Charles Flint Kellogg, NAACP: A History of the national Association for the Advancement of Colored People, vol. 1, 19091920 (Baltimore: Johns Hopkins Press 1967) at 57-62.

${ }^{7}$ Benno C. Schmidt, Jr., "A Postscript for Charles Black: The Supreme Court and Race in the Progressive Era," 95 Yale Law Journal 1681 (1985-86); and William N. Eskridge, "Some Effects of Identity Based Social Movements on Constitutional Law in the Twentieth Century," 100 Mich. L. Rev. 2062 at 2074 (2002).

${ }^{8}$ Carolyn Wedin, Inheritors of the Spirit: Mary White Ovington and the Founding of THE NAACP 113 (John Wiley \& Sons, Inc.: New York 1998). August Meier and John H. Bracey, Jr., "The NAACP as a Reform Movement, 1909-1993: 'To Reach the Conscience of America," 59 Journal of Southern History 3 (1993).

${ }^{9}$ Kellogg at 16. 
absorbed by the NAACP, and the Pink Franklin case served as a catalyst in that merger. In early 1910, the League had retained former United States Attorney General Charles Bonaparte to represent Franklin in the U.S. Supreme Court. ${ }^{10}$ Although Bonaparte wrote a brief in the case, he refused to appear at the high court. Instead, Franklin's cause was argued by his two black lawyers from South Carolina, Jacob Moorer and John Adams. Adams was a college professor and minister. Moorer was an outspoken advocate for civil rights and was known for his efforts to restore the right to vote to his fellow black citizens of South Carolina. The two lawyers represented Franklin for nearly three years. After the Supreme Court ruled against Pink Franklin on May 31, 1910, the NAACP mounted its own effort to save Franklin's life.

The chief leader of the NAACP effort was another black lawyer from South Carolina, Thomas Miller. Miller was a college president and former congressman. Miller and the NAACP enlisted the help of two white lawyers from the state to work on the case. Additionally the NAACP recruited hundreds of African American citizens from across the state, as well as a few prominent white South Carolinians, to lobby on behalf of Franklin.

This article will explore the roles of the diverse individuals and groups that worked to save Franklin. Because Pink Franklin's actions challenged Jim Crow justice, his story deserves telling. Moreover, the case of Pink Franklin v. South Carolina and the arguments it raised have an historical significance that needs to be better understood and more widely known.

\section{Troubled Fields}

"Negroes forced into one roomed cabins, mothers from their children torn

All the day till dark of evening from the dawn of early morn, 'Tis the heinous contract system that plantation life contains, Worse than slavery's conditions in a land where freedom rings." ${ }^{11}$

The story of Pink Franklin, his family, and the circumstances that led to the national campaign to save his life began in a system Lizelia Moorer considered worse than slavery. Franklin had signed a "pe-

\footnotetext{
${ }^{10}$ Letter of John Milholland to Oswald Villard, Feb. 25, 1910 (NAACP Papers).

11 "The Peonage System," Lizelia Moorer, Prejudice UnVeILed at 17 (1907).
} 
onage" contract to work on a cotton plantation owned by a white man, Jake Thomas. Cotton was truly King in the New South. In South Carolina, cotton was the number one crop in 1907. Cotton crops were increasing every year and by the end of the decade, Orangeburg County farmers produced the second largest crop among the counties of the state. ${ }^{12}$ Like cotton planters across the South, those in Orangeburg County had enjoyed a bumper crop in 1906 and had been hoping for record prices in $1907 .{ }^{13}$ But there had been drought in March and rain in April which caused the soil first to be too hard and then too muddy to plow. Consequently, Orangeburg County farmers were predicting poor crops that season. ${ }^{14}$

But life was good for the white cotton farmer compared to the life of Pink Franklin. Like Franklin, the majority of the people who labored on the plantations were black. Life was not so prosperous for these workers. There is no exact data on their wages. However, according to the state agriculture department, black farm owners made an average of only $\$ 51$ from their crops in $1907 . .^{15}$ The vast majority of blacks in the state worked someone else's land. ${ }^{16}$ So for farm laborers like Pink Franklin, the remuneration was meager indeed. Workers on cotton plantations were expected to sign a contract each year; in exchange, they were advanced some staples, a little seed, a small amount of cash, and a shack in which to live. ${ }^{17}$ At the end of the year, the black farm worker frequently owed the white plantation owner money. The Orangeburg Evening News of June 21, 1904 described the situation from the white farmers' perspective in August, 1907: "[t]his money was usually spent before the time for work began and then the farmer still had to furnish food and supplies and additional money all along during the year and wait until fall to get back the money originally advanced, by requiring them (the black laborers) to continue work under the contract until the debt is paid." Nate

\footnotetext{
12 GaVIn WRIGHT, OLd SOUth, NeW South (New York: Basic Book Publishers, 1986); and Seventh Annual Report of the Commissioner of Agriculture, Commerce and Industries of the State of South Carolina, REPORTS AND Resolutions of THE GENERAL Assembly of the State of South Carolina, p.160 (1911). Id. At 172.

${ }^{13}$ The (Orangeburg) Times and Democrat, May 23, and May 30, 1907.

${ }^{14}$ Orangeburg Evening News, June 13, 1907.

${ }^{15} / d$.

${ }^{16}$ I.A. Newby, Black Carolinians at 124 (Columbia: U.S.C. Press 1973).

${ }^{17}$ /d. at 126-127.
} 
Shaw in All God's Dangers related similar stories of the life of the black farmer. Shaw worked as a laborer, share cropper, and tenant farmer. No matter under what status he labored, Shaw remembered a life that found him deeper in debt each year and always looking for a new place to live and work. ${ }^{18}$

In the late fall of 1906, Pink Franklin and his wife left their home community and moved 12 miles to Jake Thomas' farm. Thomas was willing to supply some money, food, and a place to live to the Franklins, but the white cotton farmer required Pink Franklin to sign a labor contract. Thomas likely hired Franklin to help harvest fall crops and to plant cotton in the spring. By late May, 1907, all of the work was done, and the Franklins were unhappy with Thomas. ${ }^{19}$ Their dissatisfaction was probably caused by a bare cupboard and Thomas' refusal to advance any more food or money. Consequently, the $\mathbf{2 2}$ year old farm laborer and his $\mathbf{2 1}$ year old wife looked for a more promising place to live and work. Franklin's mother may have suggested that they move back to her home community, Willow Township, near the town of Norway. On Monday, May 20th, white farmer Charles Spires came from Willow to help move the Franklins, but they were confronted by "Mr. Jake" who would not let the couple take any of their meager furnishings. Charles and Sol Spires had known Pink Franklin and his mother, Della, for many years. ${ }^{20}$ When they arrived at the tenant house provided by Charles Spires, the Franklins were forced to lay a pallet on the floor; ${ }^{21}$ however, Sol did put Pink Franklin to work. ${ }^{22}$

${ }^{18}$ Fifth Annual Report of the Commissioner of Agriculture, Commerce and Industries of the State of South Carolina, RePORTS AND Resolutions of THE GENERAL Assembly of the State of South Carolina, p.1075 (1908); "Farmers Aroused," Orangeburg Times and Democrat, Aug. 8, 1907, p. 8. See THEOdoRe Rosengarten (COMP.), All God's Dangers: the LifE of Nate Shaw (New York: Knopf 1973).

${ }^{19}$ Charleston News and Courier, Aug. 4, 1907 and The (Columbia) State, August 1, 1907. (hereinafter referenced as The State.)

${ }^{20}$ See U.S. Census 1880 and 1900 for Willow Township, Orangeburg County, South Carolina.

21 "Got Him Safe," Orangeburg Times and Democrat, Aug. 8, 1907, p. 8. "Franklin said that he was under contract with Mr. Thomas, and that he left him on May 20 and started to move his things to Mr. Spires' place, but that Mr. Thomas wouldn't let him take them away. 'I didn't even have a bed to sleep on and just had to sleep on the floor."

${ }^{22}$ See Transcript of Record pp. 30-33. 
By late July, the weeds were thick, and it was cotton chopping time. Spires had Pink Franklin thin the cotton plants and chop grass and weeds by hand. After the handwork, Franklin had to clean out each row with a mule and plow. When the chopping was done, the cotton would be ready for picking. Pink Franklin would be expected to pick 300 pounds in a day. ${ }^{23}$

But having left Thomas' place, Pink Franklin had asserted his right to work in a place of his choosing. But his action was dangerous. In 1907, the South Carolina Criminal Code provided that if an agricultural laborer under a contract failed to perform work, the farmer could have the laborer arrested and fined $\$ 50$ to $\$ 100$ and jailed for up to 30 days..$^{24}$ The statute required the farm employer to commence the action within 30 days of the violation. On May 25, 1907 within five days of the Franklins leaving, Thomas went to the local magistrate and swore out an arrest warrant. ${ }^{25}$ But Thomas had no interest in bringing Franklin back until later when he needed him to pick cotton, and so the warrant was held for over two months by the judge until Thomas' cotton was ready.

On July 29, 1907 a constable and another man were sent by Magistrate Valentine to arrest Franklin. A deadly confrontation ensued when a constable invaded Franklin's home. Both Franklins were shot. Pink Franklin's shoulder was broken, and Patsy Franklin suffered a flesh wound to her arm. But Franklin returned fire with his "Iver Johnson" pistol, resulting in the first white man being shot in the stomach and his accomplice being wounded. ${ }^{26}$

The first intruder was Constable Henry Valentine. Valentine had broken into the Franklins' home armed with both a pistol and the arrest warrant for Pink Franklin. Issued by Valentine's brother, Magistrate Joseph Valentine, at the request of Jake Thomas, the warrant charged Franklin with violating the state's peonage statute. ${ }^{27}$ When Pink Franklin signed a contract to work, Jake Thomas assumed he could force Franklin to work as he pleased. That assumption was

\footnotetext{
${ }^{23}$ See Rosengarten generally for a description of the tasks that were to be undertaken by farm laborers as well as information about diet, housing, farming, and cotton picking.

${ }^{24}$ Act of Feb. 25, 1904, 1904 S.C. Acts 428, 429.

${ }^{25}$ Transcript of Record, p. 17.

26 Transcript of Record, p. 25 and p. 32.

${ }^{27}$ See Warrant in Transcript of Record, p. 17.
} 
supported by both law and fact..$^{28}$ Arrests for violating "Agricultural Contracts" were common. In fact, on the day that the Franklins left Thomas' place, a local newspaper matter-of-factly reported the arrest of a black farm worker for violating his contract. ${ }^{29}$

But life was changing in the cotton fields. Only three days after Franklin left Thomas' farm, South Carolina's federal judge, William $\mathrm{H}$. Brawley, issued a writ of habeas corpus for the release of Elijah and Enoch Drayton from the custody of the Charleston County sheriff. The Drayton twins were black farm laborers convicted and jailed for refusing to work under a labor contract. Judge Brawley ordered the release based on his determination that the state criminal peonage statue violated the 13th and 14th Amendments. ${ }^{30}$

The court's decision drew the immediate attention of the state's newspapers. The Charleston newspaper criticized the ruling asserting that blacks were irresponsible and would die of starvation if the "merciful white farmers did not employ them." ${ }^{31}$ The Charleston and Columbia newspapers ran front page stories about the decision on May 24th. ${ }^{32}$ The Orangeburg Times and Democrat ran an article on May 30 entitled "AGAINST LABOR LAW-Judge Brawley declares the State Statute Null and Void." ${ }^{\prime 33}$ Despite the Drayton decision, on May 25, 1903 Magistrate Joseph Valentine issued the arrest warrant for Pink Franklin. As noted above, the warrant was held until the end of July. The local press later explained the delay by claiming that Thomas did not know where Franklin was and that it took the Magistrate and his constable two months to find him. Since Thomas had confronted Charles Spires when he moved Franklin, that report was certainly false. Sol Spires also testified at the trial that Jake Thomas asked him to keep Franklin on his place until Thomas was ready to send for him. ${ }^{34}$

\footnotetext{
${ }^{28}$ Sec. 357, S.C. Criminal Code (1904).

${ }^{29}$ Orangeburg Evening News, "Violated Contract," May 20, 1907 p. 1.

${ }^{30}$ Ex parte Drayton, 153 F. 986,997 (D.S.C. 1907).

${ }^{31}$ Charleston News and Courier, May 24, 1907.

32 Id. and "Contract Labor Law Unconstitutional," The State, May 24, 1907.

${ }^{33}$ The Orangeburg Times and Democrat, May 30, 1907 p. 8.

${ }^{34}$ Transcript of Record, Pink Franklin vs. The State of South Carolina, p. 2 (Filed May 18, 1908); "Constable at Cope Shot This Morning," Orangeburg Evening News, July 29, 1907, p. 1.; Id. See Transcript of Record, testimony of Sol Spires pp. 30-33.
} 
Pink Franklin testified that he thought that he had a right to move under the terms of his contract, and that since his personal property was still at Thomas' place, he intended to return to Thomas' place. ${ }^{35}$ Prior to trial, Franklin said that he did not know anyone was trying to arrest him. ${ }^{36}$ Instead on the witness stand, he described how he came to be informed:

I did not hear anything till the door was hurled open and he came on in and busted the room door open and he said to me hands up and I did not move and he up and shot me and I fell down by my pallet when he shot me and I got my gun and fired intending to get out of the way and I got out as fast as I could. ${ }^{37}$

\section{"Negro Feared Lynching"}

\section{"Have you heard of lynching in the great United States?} 'Tis an awful, awful story that the Negro man relates,",38

Naturally, Franklin ran. Pursued by 300 white men, ${ }^{39}$ he knew they were a lynch mob. Since 1900, 31 lynchings had occurred in the state. Two of those had been in Orangeburg County and nine in neighboring counties..$^{40} \mathrm{~A} 1904$ lynching in Orangeburg County had so aroused Lizelia Moorer that she penned a poem filled with outrage, "The Eutawville Lynching." ${ }^{41}$ On June 2, 1907, George Hudson was lynched in Trenton 45 miles from Franklin's home. ${ }^{42}$ Franklin told a reporter that "he was anxious to give up before he was shot to pieces." ${ }^{43}$

The local press decried Franklin's action as "DASTARDLY," but on the day that the headlines screamed about the shooting of Valen-

\footnotetext{
${ }^{35}$ Supplemental Brief for Plaintiff in Error, Pink Franklin vs. The State of South Carolina, pp. 5-6 (1908).

36 "Got Him Safe," Orangeburg Times and Democrat, Aug. 8, 1907, p. 8.and Transcript of Record, p. 41.

${ }^{37}$ Transcript of Record, p. 41.

38 "Negro Feared Lynching," News and Courier, August 2, 1907, p. 2-A. "Lynching, "Lizelia Augusta Jenkins Moorer, Preudice Unvelleo at 31 (Boston: Roxburgh Pub. Co. 1907) reprinted in Joan R. Sherman, ed., Collected Black Women's Poetry, (New York: Oxford University Press 1988).

${ }^{39}$ Orangeburg Evening News, July 30, 1907, p. 1A.

40 Jack Simpson Mullins, "Lynching in South Carolina 1900-1914," (M.A. Thesis U.S.C. 1961) at 129-130. See also Terrence Finnegan, "At the hands of parties unknown," pp. 71-74 (Ph. D. Dissertation U. Of Ill. 1993).

${ }^{41}$ Moorer at 51.

${ }^{42}$ Ralph Ginzberg, 100 Years of Lynching 267 (New York: Lancer Books 1962).

43 "Pink Franklin in Penitentiary," The State, August 1, 1907.
} 
tine, the same newspaper reported the killing of a black man by a white man in a "contract dispute." The white man was not arrested nor pursued by a mob. ${ }^{44}$ While Franklin's would-be lynchers did not catch him, other local blacks were seized and beaten including some who "were whipped for their meddlesome insolence." ${ }^{45}$ When the mob discovered that "Parson" Nelson Rice could not swim, the Methodist minister was thrown into the river. ${ }^{46}$

The white reaction was also fueled by rumors such as the one that a black person had written a letter threatening to poison and burn "all the white people in the state." ${ }^{47}$ Others suggested that some whites had helped Franklin escape. ${ }^{48}$ Other whites were rumored to be under threat of lynching for aiding Franklin or hiring "negroes" under contracts. ${ }^{49}$ The official reaction was strong. Franklin's wife was arrested and charged with murder. ${ }^{50}$ As many as ten black citizens were arrested and charged with being accessories after the fact including a woman with a babe in her arms. ${ }^{51}$

The black community's reaction to the mob and to Franklin's plight was not passive. According to Franklin, many individuals aided his flight with food and shelter and some of them were among those arrested. ${ }^{52}$ And the black community refused to idly let innocent citizens be harassed and arrested. A mob of 30 black men tried to halt the arrest of the ten people including the baby, but the

\footnotetext{
${ }^{44}$ Orangeburg Times and Democrat, Aug. 1, 1907, p. 8.

45 "Constable's Slayer Caught," Charleston News and Courier, Aug. 2, 1907, p. 3-A.

46 "Pursuers of Franklin Threw Negro Preacher Into Edisto River," Charleston News and Courier, Aug. 3, 1907, p. 7-A.

47 "Playing with Fire." Orangeburg Times and Democrat, Aug. 15, 1907.

48 "Might Have Had Trouble," Orangeburg Evening News, Aug. 5, 1907, p. 1; "Franklin Caught Early this Morning," Orangeburg Evening News, Aug. 1, 1907, p. 1; and "Negroes Allowed to Go," Orangeburg Evening News, Aug. 7, 1907, p. 1.

49 "Might Have Had Trouble," Orangeburg Evening News, Aug. 5, 1907, p. 1; "Farmers Aroused," Orangeburg Times and Democrat, Aug. 8, 1907, p. 8.

${ }^{50}$ For example, see "Franklin Caught Early this Morning," Orangeburg Evening News, Aug. 1, 1907, p. 1; "Constable's Slayer Caught," Charleston News and Courier, Aug. 2, 1907, p. 3-A. p. 1.

51 "Franklin Caught Early this Morning," Orangeburg Evening News, Aug. 1, 1907,

52 "Got Him Safe," Orangeburg Times and Democrat, Aug. 8, 1907, p. 8 (Account given by Franklin to a reporter for The State).
} 
sheriff persuaded them to withdraw..$^{53}$ Their protest was vindicated in a few days as the local prosecutor ordered the release of the ten. ${ }^{54}$

\section{"Got Him Safe"55}

"If a white man braves the tempest and takes up the Negro's cause, He is met with ostracism and consigned to deep disgrace,"

Pink Franklin's flight was unplanned but well thought out. He first ran to Sol Spires' home, but Spires refused to help. To escape the rope, Franklin had to flee. With the help of relatives and strangers, he avoided capture. He went south along a railroad track and found his way to a white lawyer in Denmark, South Carolina, seeking both advice and refuge. Ex-Senator Stanwix Mayfield took him in and advised him to surrender. ${ }^{57}$ Franklin agreed, and Mayfield telephoned the Orangeburg County sheriff and simply invited him to come down for breakfast the next morning. ${ }^{58}$ Before the sheriff arrived, Mayfield also contacted a sympathetic reporter to interview Franklin so that his story could be told. The Charleston newspaper's story was titled "Negro Feared Lynching." 59 When Sheriff John $\mathrm{H}$. Dukes arrived the next morning, he discovered Franklin at Mayfield's home. Mayfield had also called the governor seeking protection for Franklin. Normally, the sheriff would have taken his prisoner to the Orangeburg County jail, but Governor Martin F. Ansel ordered that Franklin be transported to the state prison in Columbia for safekeeping. ${ }^{60}$ Safely delivering Franklin through the county to Columbia, ${ }^{61}$ Sheriff Dukes was personally thanked by Governor Ansel. ${ }^{62}$

\footnotetext{
53 "Constable's Slayer Caught," Charleston News and Courier, Aug. 2, 1907, p. $3-A$.

54 "Negroes Allowed to Go," Orangeburg Evening News, August 7, 1907, p. 1.

55 "Got Him Safe," Orangeburg Times and Democrat, Aug. 8, 1907, p. 8.

56 "The Truth Suppressed," at 62 in Moorer, Prejudice UnVeILed.

${ }^{57}$ Charleston News and Courier, Aug. 2, 1907, p. 2-A.

58 "Negro Feared Lynching," Charleston News and Courier, Aug. 2, 1907, p. 2-A.

$59 / d$.

60 "Got Him Safe," Orangeburg Times and Democrat, Aug. 8, 1907, p. 8.

${ }^{61}$ Maps indicate that the train would have traveled through the county seat as well as the towns of Cope and Cordova. South Carolina RallRoads Map (Chicago: Rand MCNally Co. 1900) (Library of Congress).

62 "Got Him Safe," Orangeburg Times and Democrat, Aug. 8, 1907, p. 8.
} 
Mayfield was no ordinary white South Carolinian. The former legislator was a lawyer, a cotton farmer, a lumber man, and an ardent Baptist. ${ }^{63}$ In a Baptist convention Mayfield urged his fellow whites "to take more interest in the education of the Negroes. . ." 64 He befriended black educator Elizabeth Evelyn Wright, supported her school, Voorhees Industrial School, and served on the school's Board of Trustees. ${ }^{65}$ In many ways Mayfield was the stereotypical "paternalistic" planter. ${ }^{66}$ But to Booker T. Washington, he was a "white liberal" deserving of endorsement for a federal judgeship appointment by President Taft. ${ }^{67}$ Another more telling story was an incident in 1893 when Mayfield intervened with a mob. He saved one black man's life by announcing his support for lynching but convincing the mob they had the wrong man. When another black man was seized, Mayfield again interceded and mollified the mob. However, the mob soon returned and lynched the man. Historians have debated the meaning of Mayfield's actions that day and in particular his endorsement of lynching. ${ }^{68}$ While Mayfield's words may suggest to the historian that he was no saint, his actions on behalf of Pink Franklin were life saving.

\section{Franklin Hires a Lawyer}

"As good lawyers ... who the hearts of people reach, ... If you'll listen for a moment, you will hear the Negro's voice." ${ }^{\prime 69}$

Not only had Mayfield helped save Franklin from the mob, he must have assisted Franklin to find his lawyer. That lawyer was Jacob

\footnotetext{
63 Biographical Directory of the S.C. Senate 1776-1985, Vol. II. p. 1086 (Columbia: USC Press 1986).

${ }^{64}$ Clara Johnston Hitt, The Barnwell Baptist Association 1906-1913, 11 (Greenville, S.C.: The Baptist Courier 1914).

65 J.F. B. Coleman, Tuskegee to Voormees, 52-60, 68, 71, 73 (Columbia: R.L. Bryan 1922).

66 J. Kenneth Morris, Elizabeth Evelyn Wright 202 (Sewanee: The University Press 1983). When Miss Wright called on the senator, she had to go to his backdoor.

${ }^{67}$ Booker T. Washington to William Howard Taft, May 16, 1911 in LOUIS R. HARLAN, ED. BOOKER T. WASHINGTON PAPERS, 11:158 (Urbana: University of III. Press 1989).

${ }^{68}$ Compare Stephen Kantrowitz, Ben Tillman And The Reconstruction Of White SuPREMACY 176 (Chapel Hill: U.N.C. Press 2000) with Terence Robert Finnegan, "'At the Hands of Parties Unknown': Lynching in Mississippi and South Carolina, 18811940," 131-134 Ph.D. Dissertation University of Illinois, 1993).

69 "The Voice of the Negro," Moorer at 90.
} 
Moorer of Orangeburg with whom Mayfield served on the Voorhees Board of Trustees. ${ }^{70}$ Soon John Adams of Manning was also retained as co-counsel. ${ }^{71}$ The two lawyers were quite different. A Georgia native, the 31 year-old Adams had only been a member of the bar for two years. ${ }^{72}$ Adams was both a lawyer and a minister. He attended Lincoln University, Yale Divinity School and Gammons Theological Seminary in Atlanta. When he undertook the representation of the Franklins, he was a professor at Allen University. After the Franklin case ended in 1910, Adams left the state and moved west. Eventually he settled in Omaha, Nebraska where he was a successful lawyer, state senator, an active member of the NAACP, and a nationally prominent A.M.E. minister. ${ }^{73}$ Moorer stayed in his native state. Moorer was $44 .^{74}$ Born during the Civil War, he practiced law in Orangeburg from 1896 until his death in $1935 .{ }^{75} \mathrm{He}$ was a Voorhees trustee, a Mason, a member of the Knights of Pythias, ${ }^{76}$ and a Republican who unsuccessfully ran for the state house of representatives in $1896 . .^{77}$ But he was a lawyer first and foremost. Moorer had a well-developed law practice and was an effective appellate advocate. He won five of 20 appeals he argued in the Supreme Court of South Carolina. ${ }^{78} \mathrm{His}$ earliest recorded case was in November

${ }^{70}$ Coleman, Tuskegee To Voorhees, 71.

71 "Franklin Negroes to be Tried This Week,"The State, September 4, 1907, p.1. Also see Thomas E. Miller letter to Francis Blascoer, October 27, 1910 (NAACP Papers).

72 See S.C. Roll of Attorneys and 1900 U.S. Census.

${ }^{73}$ See Who's Who in Colored America 3 (1950). Adams lived until 1961. See Nebraska Bar Association, “Proceedings, 1961," 42 Neb. L. Rev. 350 (1962).

${ }^{74}$ See the U.S. Census for 1900 as to Adams and the U.S Census for 1910 as to Moorer. And S.C. Supreme Court Roll of Attorneys.

${ }^{75}$ U.S. Census for 1910, S.C. Roll of Attorneys, and S.C. Death Certificate for Jacob Moorer. (SCDAH.)

${ }^{76}$ See Thomas Miller letter of Oct. 10, 1910 to Francis Blascore (NAACP Papers) and "Grand Lodge Officers of South Carolina Pythians" in CLement RICHARdoson, Ed., National Cyclopedia Of The Colored Race, 440 (Nat'l. Pub. Co: Montgomery, Ala. 1919).

77 See Proceedings and Returns of the State Board of Canvassers, 1868-1897, p. 586. (SCDAH).

${ }^{78}$ State v. Perry, 74 S.C. 551, 556 (1906); State v. Franklin, 80 S.C. 332 (1908); State v. Haigler, 90 S.C. 319 (1912); State v. Glover, 91 S.C. 562 (1912); In re Williams' Estate, 98 S.C. 211 (1914); Fairey v. Haynes, 101 S.C. 499 (1915) (won); Fairey v. Haynes, 107 S.C. 115 (1917) (won); Little v. Henry, 108 S.C. 230 (1917); Conner v. Grand Lodge of Pythias of S.C., 107 S.C. 308 (1917); Fairey v. Haynes, 
1898 when he appeared before the state board of canvassers on behalf of a black Republican candidate for Congress. ${ }^{79}$ Over the next decade he challenged numerous elections because South Carolina's Jim Crow constitution and laws denied the right to vote to its black citizens..$^{80}$ The arguments developed in those election cases were inventive and would serve as the primary basis for the appeal of Franklin's conviction.

His wife was also both a remarkable woman and an advocate for civil rights. Lizelia Augusta Jenkins Moorer was a librarian at Claflin University in Orangeburg. She also taught African history and was a published poet. ${ }^{81} \mathrm{Her}$ volume PREJUDICE UNVEILED was published in Boston in $1907 .{ }^{82}$ Her poetry has been described by one modern commentator as "the best poems on racial issues written by any black woman until the middle of the [20th] century." ${ }^{13}$ Her poems addressed prejudice, peonage, voting, juries, lynching, Jim Crow laws and injustice in the courts.

Regardless of their legal experience, Moorer and Adams faced a daunting task. One white lawyer later observed that the mere presence of the two black lawyers was like waving a red flag in the face of the all white jury. ${ }^{84}$ The lawyers and their clients also faced a hostile press. These accounts of the incident were always biased and often false. One Orangeburg newspaper reported that Pink Franklin

111 S.C. 132 (1918); State v. Walton, 107 S.C. 353 (1917); Bellamy v. Grand Lodge, 110 S.C. 315 (1918); State v. Danelly, 116 S.C. 113 (1921) (won); Cusack v. Sou.R.Co, 116 S.C. 143 (1921 (won); Bamberg Banking Co. v. Matthews, 109 S.C. 550 (1921 (won); Frederick v. Culler, 118 S.C. 889 (1921); Williams v. Wannamaker, 122 S.C. 368 (1923); Sandel v. Crum, 130 S.C. 317 (1924); Dantzler v. Funderburg, 129 S.C. 79 (1924); Simpson v. Antley, 137 S.C. 380 (1926).

${ }^{79}$ See Proceedings and Returns of the State Board of Canvassers, 1898-1929, (SCDAH).

${ }^{80}$ The Charleston News and Courier, Mar. 18, 1908, p. 1.

${ }^{81}$ Mamie Garvin Fields With Karen Fields, Lemon Swamp And Other Places, 101-103 (New York: The Free Press 1983).

82 Lizelia Augusta Jenkins Moorer, Prejudice Unveiled (Boston: Roxburgh Pub. Co. 1907) reprinted in Joan R. Sherman, Ed., Collected Black Women's Poetry (New York: Oxford University Press 1988).

${ }^{83}$ Sherman, Ed., Collected Black Women's Poetry at xxxii. Moorer died in May of 1939 a year after her husband's death. S.C. Death Index.

${ }^{84}$ Sawyer letter to Gonzalez, 12-17-1917 in the Pardon, Paroles and Commutations files (SCDAH). 
ambushed the constable. ${ }^{85}$ That same newspaper reported that Patsy Franklin had attacked Valentine with an axe as he lay wounded on the floor. ${ }^{86}$ Other newspapers also portrayed the Franklins as villains. ${ }^{87}$

At the Coroner's inquest on August 4th, tensions ran high. ${ }^{88}$ Although its purpose was to determine the cause of death, the hearing also became a platform for disgruntled white farmers, ${ }^{89}$ which caused Governor Ansel to order the county sheriff to prevent violence at the hearing. ${ }^{90} \mathrm{~A}$ "prominent planter" served as spokesperson for the mob, expressing anger about violations of labor contracts and concluding his remarks by threatening "summary punishment" for any person "white or colored" who violated a labor contract. ${ }^{91}$ In the end, the sheriff had to threaten the mob with arrest to preserve the peace..$^{92}$

\section{"Court Opens in Orangeburg"}

"Whites alone upon the jury in a number of states, ...

Legal ills they thrust upon him, and the tale is passing sadEqual rights with the white men ${ }^{93}$

When the trial opened a month later, the atmosphere was not much calmer. Sheriff Dukes called in constables from across the county to reinforce his deputies and the governor closed the staterun liquor store (known as the state dispensary) to prevent violence. ${ }^{94}$ Despite the atmosphere, Adams and Moorer challenged both the racial and labor order that prevailed under Jim Crow. Based on the exclusion of blacks, Adams asserted that the jury was im-

85 "Constable at Cope Shot This Morning," Orangeburg Evening News, July 29,1907, p.1.

${ }^{86}$ Orangeburg Evening News, July 30, 1907, p. 1-A.

87 "Constable Killed By Negro," Charleston News and Courier, July 30, 1907, p. 1; and "Violence Feared in Orangeburg," The State, July 30, 1907, p. 1.

88 "Valentine Inquest Held," Charleston News and Courier, Aug. 4, 1907, p. 1-A.

89 "Valentine Inquest Held," Charleston News and Courier, Aug. 4, 1907, p. 1-A.

90 "Sheriff Dukes on Hand," The State, August 3, 1907.

91 "Farmers Aroused," Orangeburg Times and Democrat, Aug. 8, 1907, p. 8.

92 "Might Have Had Trouble," Orangeburg Evening News, Aug. 5, 1907, p. 1.

93 "Injustice in the Courts," MOORER at 42.

94 "Will Come Here for Franklin," The State, Sept. 7, 1907, p.1; "Pink Franklin to be Hanged," Charleston News and Courier, Sept. 10, 1907, p. 1-A. 
properly impaneled under the U.S. Constitution. He also argued that the indictment should be quashed because of the unconstitutionality of the criminal peonage statute, citing the recent decision by Judge Brawley. ${ }^{95}$ Finally, he sought a continuance because he and Moorer had been denied access to the coroner's report. All of the defense motions were denied by Judge J.C. Klugh. ${ }^{96}$

Trial Judge Klugh was a 39-year-old University of Virginia Law School graduate who had been on the bench for 12 years. ${ }^{97}$ The four-man prosecution team was very experienced. P.T. Hildebrand of Orangeburg had been admitted to the bar in 1888 and elected Solicitor in $1901 . .^{98} \mathrm{He}$ was assisted by three other Orangeburg lawyers, W.L. Glaze, D.O. Herbert, and Robert Lide. ${ }^{99}$

The trial began on Monday, September $9 .{ }^{100}$ The state called two physicians, as well as W.M. Carter, Magistrate Valentine, Sol Spires, and three neighbors, Tony Jerry, J.H. Easterling, and Walter Hutto. Pink Franklin was the only defense witness. ${ }^{101}$ The state's evidence was that Magistrate Valentine gave his brother, Constable Henry Valentine, a warrant to serve on Pink Franklin, and that W. M. Carter was recruited to accompany the constable because Carter knew Franklin. ${ }^{102}$ The constable and Carter arrived early in the morning and asked Sol Spires to lure Franklin out. Spires went to Franklin's house and asked him to plow that day but Franklin put him off.

\footnotetext{
95 "The Franklin Case," The Barnwell People, Sept. 26, 1907, p. 4.

96 "Pink Franklin to be Hanged," Charleston News and Courier, Sept. 10, 1907, p. 1-A and "He Will Hang," Orangeburg Times and Democrat, Sept. 12, 1907, p. 10.

97 U. R. Brooks, South Carolina Bench And Bar, 292-995 (Columbia: R.L. Bryan Co. 1908).

98 Reports Ano Resolutions To The S.C. General Assembly For1901, "Report of the Secretary of State," 802 (1901).

99 "Pink Franklin to be Hanged," Charleston News and Courier, Sept. 10, 1907, p. 1-A. Roll of Attorneys, 1881, 1888, and 1894. (16 S.C. iii (1881) and 43 S.C. iv (1894)). Also see "Mayor Dukes Takes Charge," Orangeburg Times and Democrat, Sept. 26, 1907, p. 10.

${ }^{100}$ The description of the evidence is based on the Transcript of Record and the only newspaper accounts of the testimony. See Transcript of Record, Franklin v. South Carolina in the Supreme Court of the U.S. October Term 1909 (Filed May 18, 1908); "Death Sentence for Franklin," The State, Sept. 10, 1907 p. 1; and "Pink Franklin to be Hanged," Charleston News and Courier, Sept. 10, 1907, p. 1-A.

${ }^{101}$ See Transcript of Record, p. II.

102 “Death Sentence for Franklin," The State, Sept. 10, 1907 p. 1.
} 
After Spires reported back, the constable and Carter proceeded to the house. Carter claimed they found the front door open and knocked but got no answer. Carter was then sent to guard the back door, and upon arriving at the rear, he heard three shots. He immediately returned to the front, charged into the house, and was shot. Carter claimed that after the shooting he went to Spires' house where Franklin soon arrived and admitted he had "killed this other man." ${ }^{103}$ Three years later, Carter recanted his testimony and said that he had been coerced by the white mob to lie. ${ }^{104}$

Easterling and Hutto were neighbors who claimed to have talked with the dying Valentine. They testified that Valentine said he was shot by Franklin as he entered the door and was then jumped on by both Pink and Patsy Franklin. Valentine supposedly averred that Patsy had attacked him with an axe as he bled on the floor. Both Easterling and Hutto claimed that Valentine asserted he never fired a shot. However, both witnesses' testimonies are put in doubt by the statements of the two doctors. The first doctor said he administered a stimulant but Valentine never recovered consciousness enough to give any statement except to say he had been shot once. The second doctor testified that he arrived in the afternoon and found Valentine unconscious. He administered a stimulant, but the victim never responded. So both doctors administered stimulants and both testified that Valentine was not conscious enough to make any significant statements to them. Easterling's testimony was also not consistent with the physical evidence. Easterling claimed Valentine said he was shot "just as he entered the room." Both doctors said Valentine suffered one gunshot wound in the lower ribcage and that the horizontal wound was surrounded by powder burns, indicating that he was shot at fairly close range. ${ }^{105}$ One newspaper concluded that Pink Franklin's wound in his shoulder was self-inflicted during his struggle with Constable Valentine. ${ }^{106}$

The only defense witness was Pink Franklin, who testified that he heard nothing until Valentine "hurled open" the outside door and

\footnotetext{
$103 / d$. at 25.

${ }^{104}$ Thomas Miller to Frances Blascoer, December 5, 1910 (NAACP Papers).

105 "Pink Franklin to be Hanged," Charleston News and Courier, Sept. 10, 1907, p. 1-A; Transcript of Record, pp.II, 19-20, 22-23, and 39. "Death Sentence for Franklin," The State, Sept. 10, 1907 p. 1.

106 "Death Sentence for Franklin," The State, Sept. 10, 1907 p. 1.
} 
"busted the [bed]room door open." Ordered to put his hands up, Franklin tried to raise them, but Valentine shot him. Franklin admitted that he fired his gun twice, but he was not sure if he shot anyone. He stated that he was right handed and had been shot in the right shoulder, which forced him to use his left hand to fire at Valentine. ${ }^{107}$

Using his left hand is consistent with Franklin having been first shot in the right shoulder and then returning fire. Franklin denied taking Valentine's gun away from him. On cross examination, the prosecutor failed to get Franklin to admit he fired four times, and when a rebuttal witness was called by the state to prove that Franklin had previously told a reporter that he shot four times, the witness testified he was told that Valentine was the person who shot three or four times. ${ }^{108}$

Franklin's testimony certainly fit the physical evidence better than the Valentine deathbed story. Both Franklins had been shot. Franklin's testimony that he returned fire after Valentine entered the bedroom was also consistent with the powder burns on Valentine. Both treating doctors testified that the wound was surrounded by powder burns, and Dr. Heydrick said that the shooter and the victim had to be standing close to each other. ${ }^{109}$ To leave prominent powder residue, the gun had to have been shot from a range of two feet or less. ${ }^{110}$ Obviously Valentine was in the Franklins' bedroom when he was shot. The claim that he never fired his gun is inconsistent with the fact that Franklin was shot in the shoulder and Patsy Franklin was shot in the arm. The statements of the prosecution's witnesses were inconsistent with the descriptions of wounds suffered both by the Franklins and by Carter and Valentine. To make them true, Franklin would have had to first shoot both Valentine and Carter, then shoot his wife, and finally shoot himself in the right shoulder. In addition, an early newspaper account conflicted with Easterling and Hutto's trial testimony by reporting that Valentine said he

\footnotetext{
107 Transcript of Record 40-49.

108 Transcript of Record at 49.

${ }^{109}$ Transcript of Record at 20 and 23.

${ }^{110}$ See Jeffrey Scott Doyle, "Gun Residue" (http://www.firearmsid.com/A distance GSR.htm, last visited March 16, 2010).
} 
had fired his gun. ${ }^{111}$ By contrast, early accounts of Pink Franklin's story were consistent with his trial testimony. ${ }^{112}$

Franklin did admit to shooting his pistol but claimed he was not sure whom he shot. But the critical issue was not whether Franklin had shot Valentine or Carter, but whether Valentine ever identified himself as a constable or let Franklin know that he had a warrant for his arrest. Under South Carolina law, if the accused did not know the constable was a law enforcement official, he had a right to resist the arrest. ${ }^{113}$ Moreover, if he was threatened with death or serious bodily injury, he could defend himself with deadly force. ${ }^{114}$ In addition, if Franklin knew the warrant was illegal, he would have had an additional reason to resist the arrest. ${ }^{115}$ Certainly the state law offered strong defenses for Franklin. Factually, the state's case was weak on this point. Carter, the state's chief eyewitness, never claimed that Valentine announced that he was a constable or that he had a warrant. On this point, the state offered the testimony of Tony Jerry. Jerry claimed that Franklin had said the night before the shooting that "no one could arrest him."116 Presumably this testimony meant that Franklin was on notice that an arrest warrant had been issued for him. However, substantial doubt was raised on cross examination as to the credibility of Jerry. He admitted that he had been seized and beaten by the mob before the trial in the roundup of black people near the scene of the killing. ${ }^{117}$ The argument that his testimony was given under duress was well-founded. Almost three years later, Adams and Moorer obtained an affidavit from Jerry recanting his testimony and admitting he had been forced to lie. ${ }^{118}$

After the testimony was complete, Adams and Moorer moved the court for a directed verdict of acquittal as to both Pink and Patsy

${ }^{111}$ Charleston News and Courier, Aug. 4, 1907, p. 1.

${ }^{112}$ Charleston News and Courier, Aug. 2, 1907, p. 2; and Orangeburg Times and Democrat, Aug. 8, 1907, p. 8.

${ }^{113}$ State v. Byrd, 72 S.C. 104, at 107 (1905).

${ }^{114}$ Id.; State v. Brooks, 79 S.C. 144, at 149 (1908); and State v. Bodie, 33 S.C. 117 at131 (1890).

${ }^{115}$ State v. Wimbush, 9 S.C. 309 (1877).

${ }^{116}$ Transcript at 34.

${ }^{117}$ Transcript of Record at 35.

118 "Pink Franklin to Hang," The State, Sept. 7, 1910, p. 1. 
Franklin. As to Pink Franklin, the motion was based on the argument that the warrant was illegal and unconstitutional. As to Patsy Franklin, Adams rightly asserted there was no evidence presented on which to base a guilty verdict. Judge Klugh ruled that even if the warrant were null and void, he could not direct a verdict of not guilty. As to Sad Franklin, the judge said "I don't care to discuss the matter ..." and refused the motion. ${ }^{119}$

After the charge, the jury was sent out to deliberate. While the press reported the deliberations as "very short," the record of the case shows that after "remaining out for sometime" the jury returned to ask the trial judge a question. One juror in particular, L.H. Wannamaker, Jr., wanted to know if the constable had the authority to enter the house. ${ }^{120}$ Despite the law mentioned above, Judge Klugh informed the jury that the constable had a right "to tear the house down if necessary" to make the arrest and that he did not have to identify himself. Thereafter, the jury returned with a split verdict. They found Patsy Franklin not guilty and Pink Franklin guilty without a recommendation of mercy. The fact that Wannamaker held out and asked questions may indicate that he had been willing to go along if Patsy Franklin was found not guilty. Three years later Wannamaker's questions would be raised again, and his view of the case would be heard by more than the other eleven jurors. The judge sentenced Franklin to be hanged until dead on Friday, October $25,1907.121$

Appeal to the Supreme Court of South Carolina

" 'Give him freedom,' says the white man, 'will defeat our greatest plan'

With his freedom here's the trouble, he'll aspire to be a man,"122

The day after the verdict and sentence, Adams and Moorer filed a notice of appeal to the state's supreme court. The grounds for the appeal were substantial. In a remarkable admission the Columbia Record framed the case as follows:

\footnotetext{
119 Transcript of Record at 50-51.

${ }^{120}$ Transcript at 56-57.

121 "He Will Hang," Orangeburg Times and Democrat, Sept. 12, 1907, p. 10.

122 "The Pharaohs of Today," in Moorer, Prejudice UnVeILED at 26.
} 
There is no dodging the fact that, were the case not complicated by the fact that it is based upon the killing of a white man by a negro, the courts would have little trouble in arriving at a decision. The question the attorneys for the defense are by implication asking is, will the supreme court decide the matter upon the constitution, or will they be guided wholly by expediency? The defense also is confident that the supreme court must either hold that the warrant, which Constable Valentine was killed in trying to serve, was invalid, and that Franklin was, therefore, justifiable in killing one who tried unlawfully to arrest him under it, or must disregard and defy the decision of the United States court, Judge Brawley presiding, which held that the labor contract law, under which the warrant was issued, was unconstitutional. ${ }^{123}$

Another argument was an ingenious challenge to the jury selection which Moorer had developed from his work on election cases. Since jurors had to be voters registered under the restrictive provisions of the state's Jim Crow constitution of 1895, Moorer argued the jury selection was tainted because the suffrage provisions violated Congressional restrictions imposed on the state by the 1868 Reconstruction Acts. ${ }^{124}$ The lawyers also challenged the unconstitutionality of the warrant and cited numerous state law grounds..$^{125}$ These included that the judge failed to grant a continuance; admitted the dying declarations of the constable; failed to properly charge the law on self defense; improperly charged the jury that even if the warrant were null and void it did not matter; and incorrectly charged the jury that the constable could break into Franklin's house without warning.

Despite the merits of the appeal, the state supreme court was not receptive. Chief Justice Young John Pope was a Confederate veteran who had once defended the Klan. ${ }^{126}$ The associate justices were Eugene B. Gary, Ira B. Jones, and C.A. Woods. Justice Gary had read law under the tutelage of his uncle, General Matthew W. Gary, founder of the Red Shirts. ${ }^{127}$ Justice Ira Jones had been the lawyer

123 "Some More Facts in Franklin Case," Orangeburg Evening News, Sept. 14, 1907 Quoting the Columbia Record (date unknown).

${ }^{124}$ Brief of Jacob Moorer and John Adams on behalf of Plaintiff in Error, Pink Franklin against the State of South Carolina, In the United States Supreme Court, p. 3 (undated).

${ }^{125}$ See State v. Franklin, 80 S.C. 332 (1908).

126 U.R. Brooks, South Carolina Bench ANo Bar, 63-66 (Columbia: The State company 1908).

${ }^{127} / d$. at78. 
for Governor Ben Tillman and had served as a delegate to the 1895 constitutional convention, where he consistently voted to disenfranchise black citizens. ${ }^{128}$ The newest member of the court, Charles A. Woods, was the only member of the court who had never held elective office. ${ }^{129}$ Four months prior he had authored the court's opinion in Ex Parte Hollman, ${ }^{130}$ which declared the criminal peonage statute unconstitutional, but that decision was not even mentioned by the court in the Franklin case.

When the court issued its decision on March 17, 1908, The Orangeburg Evening News, ${ }^{131}$ headlined its story, "Slayer of Valentine Must Die." Chief Justice Pope wrote the opinion for the court and denied the appeal on all grounds. ${ }^{132}$ The court found no merit in the challenge to the jury selection because the state constitution and state statutes did not mention race. Naturally, Pope's opinion never addressed the issue that the 1895 constitution was adopted to disenfranchise blacks and thereby prevent them from serving on juries. The opinion was similarly dismissive of the other appellate grounds. Notwithstanding prior decisions of the court to the contrary, the decision found no merit to Franklin's claim that he had a right to defend himself and his family. ${ }^{133}$

\section{The Supreme Court of the United States}

"When appeal is made to congress for protection of the race, They promptly dodge the issue saying, 'this is not the place;

In the courts

alone there's power to decide it for a fact,'

'We evade it,' says the court-room, . ."134

Before Franklin's state court appeal was even heard, one Orangeburg newspaper predicted the case would be appealed to the U.S.

${ }^{128}$ /d. at 81; Journal Of The Constitutional Convention Of The State Of South Carouina (Columbia: Charles A. Calvo, Jr., State Printer, 1895).

${ }^{129}$ See Barry Edmond Hambright, "The South Carolina Supreme Court," Ph.D. Dissertation pp. $79-81$ (U.S.C. Dept of Gov. \& Int'I Studies 1981).

13079 S.C. 10 (1908).

131 Mar. 17, 1908.

${ }^{132}$ State v. Franklin, 80 S.C. 332, 33 (1908).

${ }^{133}$ State v. Franklin, 80 S.C. 332 at 337(1908).

134 "The Negro Ballot," MOORER at 48. 
Supreme Court. ${ }^{135}$ The article recited a full procedural history of the case including the fact that in pretrial motions:

Adams and Moorer raised three constitutional objections-two based on the federal constitution and one on the state constitution. . . One point raised was that the franchise clause in the state constitution is in violation with the act of Congress of January 15, 1868, which provided that after reconstruction the states should remain in the union with their franchise requirements unchanged. ${ }^{136}$

Pink Franklin's case drew national attention. Southern Congressmen were concerned that the case was a threat to the region's peonage system. ${ }^{137}$ Civil rights groups welcomed the opportunity to challenge this modern version of slavery. The first group to become interested in the case was the Constitution League, which had been organized in 1904 to further racial justice under the 13th and 14th Amendments. Its founders were two New York reformers, John Milholland and Mary White Ovington, who subsequently helped merge the League into the NAACP. ${ }^{138}$ The League hired former U.S. Attorney General Charles J. Bonaparte to write a brief on Franklin's behalf. ${ }^{139}$ Bonaparte, a Baltimore lawyer and grand-nephew of Napoleon Bonaparte, was supposedly paid $\$ 1,000$ for his services..$^{140}$ As Attorney General Bonaparte had tried to attack the region's criminal peonage statutes, so he was pleased by the opportunity to use Franklin's case to renew his efforts against peonage. ${ }^{141}$ However, his attitude and ego produced serious problems from the outset. For example, it appears that neither the Constitution League nor Bona-

135 "Some More Facts in Franklin Case," Orangeburg Evening News, Sept. 14, 1907 quoting The Columbia Record (date unknown).

136 "Some More Facts in Franklin Case," Orangeburg Evening News, Sept. 14, 1907 quoting The Columbia Record (date unknown).

${ }_{137}$ "Case Interests Southerners," Charleston News and Courier, Apr. 6, 1910, p. 1-A.

${ }^{138}$ See www.extramile.us/honorees/ovingtondubois.cfm and Dickson D. BRUCE, JR., ARCHIBALd GrIMKE', 147-158 (Baton Rouge: L.S.U. Press 1993).

139 Letter of John E. Milholland to Oswald Garrison Villard, Feb. 25, 1901 (NAACP Papers).

${ }^{140}$ Letter of Ed. J. Wallace to Whitefield McKinlay, Oct. 2, 1910 (NAACP Papers).

141 "Brief Filed in Franklin Case," Charleston News and Courier, April 6, 1910, p. 1-A. For a review of the early federal efforts including Bonaparte's to combat peonage, see Pete Daniel, "Up From Slavery and Down to Peonage: The Alonzo Bailey Case," 57 J. of Am. History 654 (1970). 
parte consulted with Moorer and Adams before filing the brief. Upon learning of the brief, Adams responded that the case had not been turned over to Bonaparte. ${ }^{142}$ Adams did later travel to Baltimore to confer with Bonaparte, but the only account of their meeting simply describes it as "unsatisfactory." ${ }^{143}$ One South Carolina newspaper reported that Adams and Moorer had insisted on being co-equal counsel with Bonaparte. Bonaparte did not withdraw from the case, but he failed to appear for oral arguments, prompting Adams to politely inform the Supreme Court that Bonaparte was "unavoidably detained."144

It is not surprising that Moorer and Adams did not want to turn the case over to Bonaparte. The two South Carolina lawyers may not have been as well-educated as he, but they had done a quite credible job in the trial and had obtained an acquittal for Patsy Franklin. In addition, after three years their client was still alive. They also had a fundamental difference with Bonaparte's legal approach. For Bonaparte and the Constitution League, the target was the peonage statute. ${ }^{145}$ While Moorer and Adams had fully briefed the peonage issue in their brief, their chief target was the jury selection process. ${ }^{146}$ Bonaparte had also briefed an argument entitled "The Character of the Homicide," in which the former Attorney General attempted to make the issue of self defense a federal question by citing the 13th Amendment and Sections 1990 and 5526 of the United States Revised Statutes. ${ }^{147}$ The Amendment had abolished slavery, section 1990 had abolished peonage, and Section 5526 made it a crime to hold or return a person into peonage. However, even if the arrest warrant had been unconstitutional or illegal under federal law, the gravamen of the argument remained a state law question, i.e. whether Franklin had used "reasonable force" in resisting the arrest. Although the Supreme Court could have re-

142 "Adams on Franklin Case," Charleston News and Courier, Apr. 7, 1910, p. 1-A.

143 "Why Bonaparte Played Butt-In," The State, Apr. 21, 1910, p. 1.

144 "Pink Franklin Case," Charleston News \& Courier, April 21, 1910, p. 1 A.

${ }^{145}$ Supplemental Brief for Plaintiff in Error, (Oct Term 1909).

${ }^{146}$ Brief of Jacob Moorer and John Adams on behalf of Plaintiff in Error, Pink Franklin against the State of South Carolina, In the United States Supreme Court, p. 3 (undated).

${ }^{147}$ Supplemental Brief for Plaintiff in Error at 22 (Oct Term 1909). 
jected Bonaparte's self-defense argument as not raising a federal question, it ruled instead that Moorer and Adams had not raised the issue at trial. ${ }^{148}$ This was inaccurate, because even though the two lawyers had not cited the federal statues, they had certainly argued that the arrest warrant was illegal under the 13th Amendment, both before trial and in their motion for a directed verdict. However, the Pink Franklin case was simply not the appropriate case to challenge peonage. When the Supreme Court of the United States later faced a case in which the defendant had been arrested and convicted under a peonage statute, the court reversed the conviction and declared the Alabama peonage statute unconstitutional. ${ }^{149}$

Ignored by Bonaparte was the challenge to the South Carolina constitution. This issue involved race, the right to vote, and jury service. Moorer's argument was that the South Carolina constitution's restrictions on suffrage violated the 1868 Reconstruction statute. This act had allowed S.C.'s Congressional delegation to be seated provided the state did not place any restrictions on voting beyond age, sex, and felony conviction. Defeating this interpretation was critical to white South Carolina. Attorney General J. Fraser Lyon hired Confederate veteran Daniel S. Henderson especially to argue the case. In his oral argument, Henderson began by defending the state's constitution and asserting that the Reconstruction statute itself was unconstitutional. ${ }^{150}$

Moorer and Adams hoped that a technical attack on the state's constitution would be persuasive to the high court. They had not come by their theory without forethought. In 1900 in Carter $v$. Texas, the United States Supreme Court had offered hope that lilywhite juries could be challenged. In Carter the court held that a defendant had a right to offer evidence of the exclusion of black jurors. ${ }^{151}$ Brought by black lawyer Wilford $\mathrm{H}$. Smith, the Carter case became the starting point for black lawyers across the South who

${ }^{148}$ Franklin v. South Carolina, 218 U.S. 161at 171-172 (1910).

${ }^{149}$ Bailey v. Alabama, 219 U.S. 219 (1911) and U.S. v. Reynolds, 235 U.S. 133 (1914).

150 "Pink Franklin Case," Charleston News and Courier, Apr. 21, 1910, p. 1; P.F. Henderson, D.S. Henderson, Jr., And T.R. Henderson, Eds. Life And Addresses Of D.S. HeNDERSON, 110-111 (Columbia: R.L. Bryan 1922).

151177 U.S. $442(1900)$. 
tried to use its authority to challenge the exclusion of black jurors. But subsequent cases seeking to use the Carter precedent uniformly failed because the defendants' lawyers could not produce witnesses or other evidence either that blacks had been systematically excluded from the jury pools or that the exclusions were based solely on race. ${ }^{152}$ The needed witnesses would have to have been voter registrars and clerks of court, all of whom would, of course, have been white. Indeed, although Carter stood for the right of the defendant to attempt to prove exclusion, when Wilford $\mathrm{H}$. Smith himself used the Carter case three years later to try and establish exclusion by producing the transcripts of the Alabama constitutional convention that showed the clear intent of the convention delegates to disenfranchise blacks, the Supreme Court ignored the evidence..$^{153}$ If the very words of the white Southern leaders were not enough, how could Moorer and Adams establish their case, since they of course had not and presumably could not have produced any witnesses who would have testified about the racial intent of the white officials in Orangeburg County?

The two lawyers argued that the 1868 Reconstruction statute should prevail over the state's constitution. Under this theory, they did not have to prove an intent to exclude blacks; he simply had to show that South Carolina law contravened federal law. This was not a frivolous argument. ${ }^{154}$ It had been used in a number of Congressional election challenges, at least once successfully. ${ }^{155}$ In another

152 See Tarrance v. Florida, 188 U.S. 519 and Brownfield v. S.C., 189 U.S. 426.

${ }^{153}$ Giles v. Harris, 189 U.S. 475 (1903).

${ }^{154}$ It could be argued that the two lawyers were ahead of their times. The logic of federal statutory law overriding state laws on voting rights was what made the 1965 Voting Rights Act so successful.

${ }^{155}$ In seating Thomas E. Miller in the 1888 Miller vs. William Elliott Seventh Congressional District contested election case, the U.S. House of Representatives, declared the 1881 South Carolina registration law unconstitutional. The Minority Report of the Committee (House Report No. 2502, Part 1, 51st Cong. 1st Session, pp. 1-25) is dated June 20,1890. The report was adopted by the House, and Miller was seated. In the Thomas B. Johnston v. J. William Stokes case, the House Committee on Elections noted that its 1888 counterpart found the South Carolina registration law unconstitutional and agreed with that determination. House Report No. 1229, 54 Congress, 1st Session, April 13, 1896, pp. 18-20. In these cases, the challenge was not to the state's constitution but to the state's statutes. A similar argument had been used in a Mississippi case, Sproule v. Fredericks, 69 Miss. 898, 11 So. 472 (May 23, 1892). Fredericks made the argument that the 1890 Missis- 
election contest for South Carolina's Seventh Congressional district in 1904, the U.S. House Committee on Elections rejected the argument, but invited the Supreme Court of the United States to decide the issue. ${ }^{156}$ Moorer had represented the losing candidate in that case. When the House Committee on Elections decided the contest, the New York Times ran the following headline: "Dodges Negro Vote Decision-House Committee says Supreme Court Must Pass on Disfranchising Laws." ${ }^{157}$ As reported by the Times, the house committee noted that if they granted relief to the black Republican they would have to unseat every House member from a Southern state. In the Franklin case, the Supreme Court of the United States rejected Moorer's novel argument as well, treating Franklin like all other black defendants who claimed discrimination in jury selection. The Court held that Franklin's lawyers had failed to present any evidence to support an intent to discriminate, and therefore, the case did not meet the requirements of Carter v. Texas. ${ }^{158}$

\section{The Governor}

\section{"Tell me not of shame or failure in a just and righteous cause, For the right at length will triumph in the face of wicked laws,"159}

The failure to persuade the court to overturn Franklin's conviction was sober news and the press described it as "Franklin's Last Hope Gone." ${ }^{160}$ Despite the defeat, Moorer and Adams did not give up. They began a petition drive to the governor for clemency. ${ }^{161}$

sippi State Constitution violated the Reconstruction Act of 1870 readmitting Mississippi to representation in the U.S. Congress. The first use of the 1868 Reconstruction statute appears to have been made in Mills v. Green, 67 F. 852 (C.C.D.S.C. 1895), rev'd Green v. Mills, 69 F. 852 (4th Cir. 1895) appeal dismissed, 159 U.S. 651. However, the federal preemption issue was not addressed by the courts. For additional discussion, see W. Lewis Burke, "Killing, Cheating, Legislating, and Lying: A History of Voting Rights in South Carolina after the Civil War," 57 S.C. Law. Rev. 859 (2006), and R. Volney Riser, Defying Disfranchisement, (Baton Rouge 2010).

${ }^{156}$ United States, House of Representatives, 58th Congress, 2d Session, Report No. 17, Alexander D. Dantzler v. Asbury F. Lever, March 18, 1904.

257 New York Times, March 19, 1904.

${ }^{158}$ Franklin v. South Carolina at 166-167.

159 The Negro Ballot," MOORER at 49.

${ }^{160}$ Charleston News and Courier, June 1, 1910, p. 1-A.

161 "Some Talk About Town," The State, June 29, 1910. 
They also filed a motion for a new trial based on the affidavit of witness Tony Jerry; in it Jerry retracted his trial testimony that Pink Franklin showed him a gun and stated that he would not allow anyone to arrest him. ${ }^{162}$ This strategy bought only minimal time; the motion was quickly denied by a state circuit court judge, and Franklin was re-sentenced to hang on December 23, 1910. This ruling was appealed to the state supreme court. ${ }^{163}$ Within days, however, the need to find a successful strategy grew even more urgent, when virulent racist Cole Blease won the Democratic run-off primary for governor. ${ }^{164}$

Governor Martin Ansel would leave office in January, so a clemency request petition would have to reach him before then. Moorer and Adams' initial plan was to obtain the signatures of the jurors and the prosecuting attorney on the petition. Immediately, the solicitor refused. ${ }^{165}$ The plan to obtain the signatures of the jurors was not entirely foolish, because one juror ultimately did call for the commutation of the death sentence. ${ }^{166}$ However, there is no record that Moorer and Adams ever obtained any juror's signature or presented a clemency petition to the governor. Fortunately, the effort to save Franklin was taken up by others.

Housed in the same offices as the Constitution League, the NAACP had become aware of the League's efforts on behalf of Franklin even before the Supreme Court had ruled. ${ }^{167}$ However, Franklin's did not become the first legal cause undertaken by the NAACP until July 23, 1910, when Boston lawyer and NAACP activist Albert E. Pillsbury wrote the association's executive secretary, Frances Blascoer, suggesting that the NAACP draft a clemency petition for

${ }^{162}$ The State, September 7, 1910, p. 1.

${ }^{163}$ The State, September 9, 1910, p. 1 and November 10, 1910, p. 10.

${ }^{164}$ See The State, September 14, p.1, September 15th, p. 1, and September 16 p1. Blease had openly endorsed lynching and was supported by the Klan. See WALTER EDgar, SOUTH CAROLINA: A Historr, 468, 473-75, and 484. (Columbia: U.S.C. Press 1998).

${ }^{165}$ The State, June 26, 1910, p. 1.

${ }^{166}$ See Letter L.H. Wannamaker on letterhead of the News and Courier to Governor Martin F. Ansel, Dec. 3, 1910. Pardons, Paroles and Petitions for Pardon File in the Papers of Governor Martin F.Ansel (S.C.D.A.H.).

${ }^{167}$ Milholland to Villard, Feb. 25, 1910. (NAACP Papers). 
Franklin. ${ }^{168}$ Pillsbury assumed Moorer and Adams would be helpful in circulating the petition, but within days a prominent black leader in South Carolina, Thomas Miller, notified the chairman of the organization that the "honorable" white men of South Carolina would not help as long as Moorer and Adams were associated with the case. ${ }^{169}$

Thomas E. Miller was the titular head of the black community in South Carolina. ${ }^{170} \mathrm{~A}$ native of the state, Miller had been educated at Lincoln University in Pennsylvania. Admitted to the bar in 1875, he rose to prominence during Reconstruction, serving in the state legislature and being elected to the U.S. Congress in 1888. Miller was a delegate to the 1895 Constitutional Convention and strenuously fought adoption of the provisions that disenfranchised black voters. As president of South Carolina's only public college for blacks, Miller was certainly a man who had to be heeded. As soon as he was contacted about the petition drive, he advised that Adams and Moorer be removed from the case. He also suggested the NAACP associate some white South Carolina lawyers, abandon Franklin's appeal, and petition the governor using only the signatures of South Carolinians. ${ }^{171}$

Miller and Bonaparte shared the view that Moorer and Adams had not properly represented Franklin. ${ }^{172}$ But Bonaparte saw no need to petition the governor and proposed instead that John $D$. Rockefeller be recruited to make "a personal and individual appeal to the governor on Pink's behalf." ${ }^{173}$ Bonaparte granted that Miller might be right in suggesting the hiring of "white, South Carolina lawyer ... paid a moderate fee (Southern lawyers, anyhow do not get very large fees)." ${ }^{174}$ Soon Blascoer sent Miller fifty dollars and a

168 Albert E. Pillsbury to Blascoer, July 26, 1910 (NAACP Papers). Pillsbury was one of the founders of the Boston chapter of the NAACP. Mark Schneider, "The Boston NAACP and the Decline of the Abolitionist impulse," Mass. Hist. Rev. 1:95 (1999).

${ }^{169}$ Thomas E. Miller to William English Walling, July 29, 1910 (NAACP Papers).

${ }^{170}$ William C. Hine, "Thomas Ezekiel Miller," in Walter Edgar, Ed., THE South CarOLINA ENCYCLOPEDIA 635-636 (Columbia: USC Press 2006).

${ }^{171}$ Miller to Walling, July 29, 1910 (NAACP Papers).

172 Miller to Walling, July 29, 1910 (NAACP Papers) and Bonaparte to Blascoer, July 30, 1910 (NAACP Papers).

173 Bonaparte letter to Frances Blascoer, July 30, 1910 (NAACP Papers).

${ }^{174}$ Bonaparte to Blascoer, August 10, 1910. 
draft petition that was probably written by W.E.B. DuBois. ${ }^{175}$ Miller re-wrote the petition into what he called "an inoffensive but very strong petition," and distributed 500 copies to "fearless, conservative men to help me securing signatures in each and every county in the state." ${ }^{176}$ For $\$ 100$, he hired Claude Sawyer, a white lawyer from Aiken, S.C. who served on the board of trustees of Miller's college, and he recruited Benjamin Hagood, a white lawyer from Charleston, who refused compensation. ${ }^{177}$

Frances Blascoer proved invaluable. As executive secretary of the NAACP, she was the organization's contact person for Miller. In the early days of the campaign, she rallied both human and financial support. The human support was phenomenal. Although a petition from outside the state seemed impolitic to some, a letter writing campaign was launched. President William Howard Taft wrote to Governor Ansel on Franklin's behalf in both August and September. ${ }^{178}$ Booker T. Washington, while not a member of the NAACP, apparently urged some of his supporters to contact the governor or other persons of influence in the state. ${ }^{179}$ Some such as Adam Clayton Powell sent checks. ${ }^{180}$ Others contacted Moorer and Adams to try and convince them to withdraw from the case. Chief among these were W.E.B. DuBois from the NAACP and New Yorker lawyer Thomas Ewing. ${ }^{181}$ DuBois had met Adams previously in a visit to the state, ${ }^{182}$ and Ewing had been consulted by Moorer and Adams about the case, so both DuBois and Ewing had reason to believe they could influence the two lawyers. Newspaper attention was garnered with stories and editorials appearing across the country. ${ }^{183}$ In fact,

${ }^{175}$ Letter of Villard to Blascoer, August 4, 1910. (NAACP Papers).

176 Miller to Blascoer, August 13, 1910. (NAACP Papers).

177 Miller to Blascoer, August 13, 1910. (NAACP Papers).

178 Taft to Ansel, August 29, 1910 and Sept. 10, 1910 (William Howard Taft Papers) Also see Ansel to Taft, Sept. 9, 1910. (NAACP Papers).

179 "Pink Franklin's Reprieve," The Crisis, p. 15 Feb. 1911.

${ }^{180}$ See letters of Adam Clayton Powell to English Walling, August 18, 1910 and August 23, 1910. (NAACP Papers).

${ }^{181}$ DuBois to Adams and Moorer, Oct.13, 1910 and Thomas Ewing to Adams, Oct. 17, 1910 (NAACP Papers).

${ }^{182}$ The State, February 28, 1907.

${ }^{183}$ See The Washington Bee, April 16, 1910, New York Times, May 31, 1910, The Washington Herald, June 1, 1910. For example, see "The Pink Franklin Case," The State, June 21, 1910 citing editorials and stories in the New York Post and The Indianapolis News. 
outside influence played a major role in the effort to save Franklin's life.

The most crucial outsider was Blascoer. As Miller pursued his strategy to hire white lawyers and launch the petition drive, the effort to persuade Moorer and Adams to resign from the case was not progressing. One of Miller's contacts spread the false rumor that Moorer and Adams were demanding to be paid $\$ 1,000$ before they would withdraw. ${ }^{184}$ Later, Miller admitted the mistake, but by then the attacks on Moorer and Adams had engendered distrust and suspicion. ${ }^{185}$ In late October, Albert Pillsbury wrote Blascoer and suggested she "journey to the spot." ${ }^{186}$ She heeded Pillsbury's suggestion and traveled to Orangeburg, South Carolina, where she conferred with Miller and met with Moorer and Adams and later with Pink Franklin. According to Blascoer, while Moorer and Adams proved difficult, they were not impossible. ${ }^{187}$ She visited Pink Franklin at the state penitentiary and obtained his signature on a document appointing her as his "attorney in fact" and relieving Moorer and Adams as his attorneys. ${ }^{188}$ She then met with Claude Sawyer and Benjamin Hagood, the two white lawyers recruited by Miller. ${ }^{189}$ Probably at the suggestion of Oswald Villard, Blascoer obtained a meeting with Ambrose Gonzales, the Editor of The State newspaper in Columbia. ${ }^{190}$ The meeting with Gonzales was quite fruitful, just weeks before, his newspaper had asserted that Franklin had entrapped the constable and called Franklin "a dangerous beast." ${ }^{191}$ But Blascoer won over Gonzales. The editor not only called the governor, but also, in an about face, the newspaper carried a sympathetic story. ${ }^{192}$ Blascoer finally persuaded Moorer and Adams to withdraw from the case. ${ }^{193}$ Adams was paid $\$ 115$ for his

\footnotetext{
${ }^{184}$ Wallace to McKinley,Oct. 10, 1910 (NAACP Papers).

185 Miller to Blascoer, Oct. 27, 1910(NAACP Papers).

186 Pillsbury to Blascoer, Oct. 27, 1910 (NAACP Papers).

${ }^{187}$ Blascoer to Villard, Nov. 4, 1910, Nov. 7, 1910 . (NAACP Papers).

${ }^{188}$ Affidavit of Franklin dated Nov. 4, 1910 (NAACP Papers).

${ }^{189}$ Blascoer to Villard, Nov. 7, 1910.

190 Blascoer to Villard, Nov. 4, 1910.

${ }^{191}$ The State, June 21, 1910, p. 4.

192 Blascoer to Villard, Nov. 4, 1910.

193 Blascoer to Pillsbury, Nov. 14, 1910 and telegram of Adams to Blascoer, Nov. 22, 1910 (NAACP Papers).
} 
expenses and Moorer even less; these payments were substantially less than the rumored demand. ${ }^{194}$ Blascoer's whirlwind visit culminated with a visit to Governor Martin Ansel, and while there is no transcript of the meeting, the result suggests that the governor was favorably impressed by her presentation on behalf of Pink Franklin.

When she returned to New York, Miller wrote her, praising her visit as producing "great good to Franklin." 195 She immediately renewed the NAACP campaign to raise money to assist with the case asking such individuals as Jane Addams and Julius Rosenwald to contribute. ${ }^{196}$ In South Carolina, Thomas Miller continued his efforts with Sawyer and Hagood to seek a commutation of the death sentence. ${ }^{197}$ Normally a governor would not commute the sentence in a case still under appeal. Naturally, the lawyers were nervous about withdrawing the appeal filed by Moorer and Adams without some indication that the governor would grant relief, ${ }^{198}$ so they met with Governor Ansel to assure themselves that it was really safe to discontinue the appeal. ${ }^{199}$ After the meeting, Miller expressed confidence that once the appeal was withdrawn, a quick commutation and the release of Franklin would follow. ${ }^{200}$

There were other signs of hope. In addition to the Columbia newspaper's change of heart, the Charleston News \& Courier called on the governor to show mercy to the "wretched, ignorant"

${ }^{194}$ Adams to Blascoer, Nov. 22, 1910. Moorer said his expenses were between $\$ 70$ and $\$ 80$. See Miller to Blascoer, Oct. 10, 1910 (NAACP Papers). The Attorney General of South Carolina received reimbursement of $\$ 73.50$ for his trip to Washington, D.C. to argue the Franklin case. There is no record of what his co-counsel's expenses were. However, considering the travel to Washington, travel to Baltimore by Adams to meet with Bonaparte, printing of the briefs and records, it is clear that the expenses sought by Moorer and Adams were simply nothing more than reimbursement for their expenses. See Reports Ano Resolutions Of The General AsSEMBLY, Vol. V (1911 Gonzales and Bryan, State Printers) "Report of J. Fraser Lyon Attorney-General to the General Assembly of South Carolina for the Fiscal Year, 1910." at p. 804.

195 Miller to Blascoer, Nov. 11, 1910 (NAACP Papers).

196 See Letters to Addams and Rosenwald, 11-15-1910.

197 See letters of Miller to Blascoer, Nov. 22, 25 and 29, 1910 (NAACP Papers).

${ }^{198}$ For example, see Adams and Moorer to DuBois, Oct. 17, 1910 and Miller to Blascoer, Nov. 25, 1910.

${ }^{199}$ Miller to Blascoer, Nov. 25, 1910 and Dec. 1, 1910 (NAACP Papers).

${ }^{200}$ Miller to Blascoer, Nov. 25, 1910 and Dec. 1, 1910. (NAACP Papers). 
Franklin. ${ }^{201}$ When it was announced in mid-December that the constable's family had garnered over 500 signatures of whites from Orangeburg County on a petition to the governor, The State opined that even if 50,000 signatures were on the petition, justice demanded that the governor commute Franklin's death sentence. ${ }^{202}$ Even trial judge J.C. Klugh wrote to the governor and expressed the view that if Franklin had been white he would never have been convicted. ${ }^{203}$ However, white pressure to hang Franklin did not subside and the governor insisted on seeing Prosecutor Hildebrand and members of the Valentine family. ${ }^{204}$ The mother of the deceased constable wrote to Ansel, "Oh God please help the Gov. to decide in my poor favor and not those troublesome Negroes." 205

When Miller, Sawyer, and Hagood met with the governor on December 5 th, they were able to cite the support of the Attorney General of South Carolina, letters from juror L.H. Wannamaker and trial judge Klugh, and the fact that W.M. Carter had recanted his testimony that Franklin admitted shooting Valentine. ${ }^{206}$ By the middle of the month Franklin's new lawyers presented a petition for pardon to the governor which included 975 signatures from 18 counties. Most, if not all, of the signatories were black. ${ }^{207}$

By mid-December Miller attempted to see the governor again and wrote him a pleading letter reminding him that the execution was scheduled for December 23. ${ }^{208}$ On December 17th, the governor surprised everyone when he granted a reprieve of the execution until January $27,1911 .{ }^{209}$ If a reprieve was all that could be achieved,

${ }^{201}$ Dec. 5, 1910.

${ }^{202}$ The State, Dec. 16, 1910.

${ }^{203}$ J.C. Klugh to Ansel, Dec. 10, 1910, Governor Martin Ansel's Papers (SCDAH).

204 Miller to Blascoer, Dec. 5, 1910 (NAACP Papers) and Hildebrand to Ansel, Dec. 6, 1910 Papers of Martin Ansel (SCDAH).

${ }^{205}$ Letter from Mrs. M. Ella Valentine, mother of deceased, Dec. 12, 1910 in the Papers of Governor Martin F. Ansel (SCDAH).

${ }^{206}$ Miller to Blascoer, Dec. 5, 1910. Also see Letter of L.H. Wannamaker to Ansel, Dec. 3, 1910 in Pardon File of Governor Ansel. (SCDAH).

207 See petition for Pardon, Petition of Pink Franklin, Pardon Book, Page 66 dated Dec. 16, 1910 in Pardons, Paroles and Petitions for Pardon File in the Papers of Governor Martin Ansel (SCDAH).

${ }^{208}$ Miller to Blascoer, Dec. 15, 1910 and Miller to Ansel, Dec. 15, 1910.

${ }^{209}$ Respite of Death Sentence by Gov. Ansel sent to Sheriff A.M. Salley of Orangeburg, Dec. 17, 1910. (SCDAH). 
Franklin was doomed, because Governor-elect Cole Blease would be inaugurated before the new execution date. The prosecutor and the constable's family met with the governor on December 20 or 21st. ${ }^{210}$ On December 20, a nervous Miller urged Hagood to beseech the governor to act. ${ }^{211}$ Two day later, Hagood telegraphed Blascoer in New York that circumstances looked favorable for a commutation and that no further action was advisable. ${ }^{212}$

On January 5, 1911, Governor Martin Ansel commuted Pink Franklin's sentence to life imprisonment. ${ }^{213} \mathrm{His}$ decree cited the evidence in the case, the petitions for clemency, and the trial judge's support for commutation as the reasons why he acted. ${ }^{214}$ While Franklin's life had been saved, Miller expressed disappointment that the sentence had not been reduced to ten years and expressed the fear that Franklin would be assigned to hosiery mill, the worse work section of the prison. ${ }^{215}$

\section{Prison, the Chain Gang, and Freedom}

"Fed with only bread and water and for more they dare not fret, They are worked like beasts of burden and the story here is told, Of the sacrifice of manhood to a god that's made of gold!"1216

Once Pink Franklin's life was spared, he became just another inmate in the state penitentiary. As Thomas Miller had feared, Franklin was assigned to work in the hosiery mill. He worked there until the spring of $1914 .{ }^{217}$ Miller's warning that the hosiery mill was

\footnotetext{
${ }^{210}$ Miller to Villard, December 16, 1910.

211 Miller to Hagood, Dec. 20, 1910.

212 Telegram of Hagood to Blascoer, Dec. 22, 1910.

${ }^{213}$ See telegram from Gonzales to Villard, Jan. 6, 1911. (NAACP Papers).

214 "Franklin Will Not Hang," The State, January 6, 1911.

215 Miller letter to Blascoer, January 8, 1911.

216 "Peonage," in MOORer at 18.
}

${ }^{217}$ See The Hosiery Mill Time Books, July 1910-March 1911 and April 1911-November 1911. Local Prisoners Book (\$132007) p.118; Prisoners discharged for the year of 1914. Record of Deaths, Discharges, Escapes, Pardons \& Paroles (S132008) p. 278 (SCDAH); His prison record reads as follows: No. 18353, Name: Pink Frankling [sic]Age: 25, Sex: M, Color: C, Nativity: Orangeburg Co., Height: 5-10, Hair: Black Eyes: Blk, Complexion: Mulatto, Offense: Murder, At what Court: Orangeburg Co. Jan 1911[2], Sentenced to Hang Communted to life by Gov. Ansel. Lost to Orangeburg CO. by commutation of sentence Feb 18, 1914., Expiration: Death, Central Register of Prisoners, Department of Corrections (SCDAH). 
the "worse section of the prison" was well-founded. The hosiery mill was called the "tuberculosis incubator" and was eventually condemned by Governor Cole Blease. ${ }^{218}$

There is no record that any of Franklin's lawyers worked on his behalf after 1910. Governor Blease dismissed Thomas Miller as president of the state college in Orangeburg. Miller moved to Charleston where he was active with the NAACP for a time, but he soon faded from the scene. ${ }^{219}$ Frances Blascoer left the NAACP and found other progressive causes. ${ }^{220}$ John Adams moved to Colorado and then Nebraska where he had a long career in the law and in politics. 221 Jacob Moorer continued to practice law in Orangeburg. But the NAACP did not forget Franklin. In April of 1914 Oswald G. Villard wrote Ambrose Gonzales to inquire about Franklin, and Gonzales informed him that Governor Blease had reduced Franklin's sentence from life to 90 years and transferred him to the chain gang back in his home county. ${ }^{222}$ Pink Franklin had written a plea to Governor Blease the previous December, and the governor had reduced the sentence and transferred Franklin on February 17, 1914. ${ }^{223}$ One year later, in February, 1915, Franklin wrote Blascoer from the chain gang in Bowman, S.C. asking for further help. ${ }^{224}$ This prompted a series of letters among NAACP representatives, Bonaparte, Hagood, Sawyer, and Gonzales, but Franklin remained on the chain gang. ${ }^{225}$

${ }^{218}$ Annual Message of Governor Cole L. Blease to the General Assembly, January 14, 1913 in Reports And Resolutions Of The General Assembly Of The State Of South CARolina, Vol. III at 175-176 (Columbia: Gonzales and Bryan, State Printers 1913).

219 Hine, "Thomas E. Miller," The South Carolina Encrclopedia.

${ }^{220}$ Mary White Ovington, Black And White Sat Down Together, 69 (New York: The Feminist Press 1995).

221 "State Senator Adams Dies," Omaha World Herald, April 21, 1962 and J. CLAY SMith, Emancipation 465 (Philadelphia: U. of Penn. Press 1993)..

222 Gonzales to Villard, May 1, 1914.

${ }^{223}$ Letter of Pink Franklin to Blease, Dec. 15, 1913 and commutation issued Feb. 17, 1914. Pardon file of Governor Cole Blease (SCDAH).

224 Franklin to Blascoer, Feb. 15, 1915 (NAACP Papers).

225 Unidentified to Gonzales, April 15, 1915, ,Gonzales to Villard, July 10, 1915, Secretary to Gonzales, July 30, 1915, Unidentified to Hagood, Sept. 15, 1915, Unidentified to Bonaparte, Sept. 30,1915, Unidentified to U.S. Supreme Court Oct 7, 1915, Hagood to Spingarn, Oct. 29, 1915, Sawyer to Spingarn, Oct. 28, 1915, Bonaparte to Nerney, Nov. 1, 1915, Spingarn to Nerney, Dec. 10, 1915, Nerney to Gonzales, Dec. 11, 1915, Bonaparte to Nerney, and Dec. 13, 1915 (NAACP Papers). 
Franklin was assigned to "Gang Number 3"226 in Bowman. In September of 1917, this camp was the subject of an official report by the state corrections board. ${ }^{227}$ The camp had 19 "convicts" all of whom were black. The chain gangs were not a death trap like the hosiery mill, but conditions were primitive and punitive. This particular camp was criticized for being located near a swamp, which increased the exposure to mosquitoes. While trusties were housed in tents, the majority of the inmates were housed in wagons so that they could be moved as roads were built. The wagons resembled circus wagons used to transport lions and tigers. The steel slats of the wagons provided plenty of ventilation in the summer but no protection from mosquitoes and other pests. In the winter, the prisoners were protected from the cold only by canvas flaps and their own body heat. At the time of the report, the wagons or "cages" in the Bowman camp were not even equipped with sufficient bunks so that each man had a bed. While chain gangs offered opportunities for inmates to see their families on visiting days, the men were subject to severe discipline and were often chained at the ankle as they worked. ${ }^{228}$ How Franklin was treated is not recorded, but we know he survived because in January of 1919, Governor Richard Manning paroled him. Gonzales had never given up trying to convince the governor to look into the case, and on the last day of his term, Manning granted Franklin his freedom. ${ }^{229}$

The NAACP lost all contact with Pink Franklin. According to official records, he simply disappeared. However, it is now clear that he took a new name and moved with his family about 20 miles away from Willow Township. According to the 1920 and 1930 censuses, Mack Rockingham was living with Patsy Rockingham, Pink Rockingham and Nolan Rockingham in the Blackville Township in Barnwell County. Not only did Mack Rockingham have a wife and

${ }^{226}$ Villard to Gonzales, April 15, 1915 (NAACP Papers).

${ }^{227}$ Reports Of State Officers Boards And Committees To The General Assembly Of The State Of South Carolina, vol. II ,Third Annual Report of the State Board of Charities and Corrections of South Carolina to the Governor 176-177 (Columbia: Gonzales and Bryan State Printers 1918).

228 Reports Of State Officers Boards And Committees To The General Assembly Of The State Of South Carolina, Chp. XV, "County Chain Gangs: Scores and Costs," 89-100 (Columbia: Gonzales and Bryan State Printers 1917).

${ }^{229}$ A.E. Gonzales to Villard, January 24, 1919 (NAACP Papers). 
children with the same names as Pink Franklin's wife and children, Rockingham was the same age and skin color as Franklin. ${ }^{230}$ Any doubt that Mack Rockingham was Pink Franklin was erased in 1949 when he died in rural Blackville. There is not actually a death certificate for Mack Rockingham, but there is one for Mack Rockingham Franklin. On this death certificate, "Franklin" was added on to Mack Rockingham's name as well as to Patsy Rockingham's name. Also listed as Franklin's mother is Della Parlor. ${ }^{231}$ In both censuses Rockingham is listed as a farmer. Neither record shows whether he owned land but the 1920 census does record that he was farming "on account" or sharecropping. His death certificate simply says he did "farm work."

\section{CONCLUSION}

"Tell me not of shame or failure in a just and righteous cause, For the right at length will triumph in the face of wicked laws, . . .232

Saving Franklin's life demonstrated that legal efforts could achieve meaningful results. The actions of blacks and whites from the South and from across the nation demonstrated the power of a biracial, multi-class coalition. Of course, as Richard Kluger has written, the case also taught the NAACP the lesson that the "rescue-operation approach" presented severe limitations to an organization trying to change the world. ${ }^{233}$

But there were other lessons to be learned from the case. Pink Franklin was a black man willing to defend his family against an armed white man. Despite the odds against him, he escaped from a lynch mob and used the legal system to save himself. We do not know how much Pink Franklin cared about the legal issues, but without question, he benefited by the efforts made on his behalf by Moorer and Adams as well as Miller and the NAACP. To Jacob Moorer and his wife, Lizelia Moorer, the Pink Franklin case was

${ }^{230} 1920$ and 1930 United States Federal Census for South Carolina, Barnwell County.

${ }^{231}$ Standard Certificate of Death, Division of Vital Statistics, State Board of Health, State of South Carolina, State file No. 49-007955. (August 12, 1949). The cause of death is listed as prostate and liver cancer.

232 "The Negro Ballot," MOORER at 49.

233 Richard KLUGer, Simple JUSTICE, 101 (1976). 
about the ballot. Like most of her poems, "The Negro Ballot" quoted above ends with a hopeful prayer, albeit a prayer that was not answered for decades. The Pink Franklin case represents more than just the NAACP's first entry into the legal world. The differences between the aims of the NAACP and of Moorer and Adams have led to a failure by modern historians to appreciate the case. The NAACP wanted to attack peonage and to save Franklin's life. Moorer and Adams wanted to attack the jury selection and to save Franklin's life. The NAACP came to the case through the efforts of the Constitutional League and the legal persuasion of Charles Bonaparte. Jacob Moorer came to the case because he was the only black lawyer in Orangeburg County. While he had his own political and legal agenda, Moorer was a black man who knew the indignity of being a black lawyer in a racist judicial system, of losing in rigged elections, and worse, of seeing his clients convicted by an illegitimate legal system. Bonaparte's and the NAACP's outside views were more limited, but it is the NAACP's memory of the case which has been preserved by scholars.

The longest treatment of the Franklin case is found in a Yale law journal article by Benno C. Schmidt, Jr. Schmidt's recounting of the Franklin case is erroneous in identifying the wounded as a sheriff, a deputy, and the baby Franklin, but Schmidt's gravest error is found in a footnote. In it, Schmidt says Franklin's black South Carolina lawyers' "handling of the case in the state courts was patently inadequate ..."234 Schmidt is clearly sympathetic to Franklin and even criticizes Justice William Day's treatment of the jury issue as "wooden" and failing to address how the Jim Crow jury system worked in South Carolina. But like all others who have written about the case, Schmidt attacks the abilities of Moorer and Adams without mentioning their legal strategy to challenge South Carolina's constitution and its franchise provisions. While the argument did not succeed, the efforts of Moorer and Adams to save Pink Franklin's life and to attack Jim Crow deserve to be remembered.

It took decades before the NAACP trusted black lawyers with its legal cases and decades before Charles Hamilton Houston would take charge of the assault on Jim Crow. It also took years before

${ }^{234}$ Benno C. Schmidt, Jr., "A Postscript for Charles Black: The Supreme Court and Race in the Progressive Era," 95 Yale L. J. 1681 (1985-86). 
the NAACP recognized the importance of voting rights cases. Darlene Clark Hine documented the story of the NAACP and the struggle for voting rights in Black Victory: The Rise and Fall of the White Primary in Texas. ${ }^{235}$ The 20-year battle ended in victory in the Supreme Court with the 1944 case of Smith v. Allwright. ${ }^{236}$ Hine is of the opinion that the Texas voting cases helped launch the modern Civil Rights movement which has been called the "second Reconstruction." 237 In the 2003 edition of the book, Steven Lawson notes that Hine's observation is correct to the extent that "victory finds a hundred fathers, but defeat is an orphan." ${ }^{238}$ Lawson goes on and notes that the DNA of the Civil Rights movement "comprises a multiplicity of causative markers." The Pink Franklin case may not rate a place on the list of the great ancestors of the modern Civil Rights movement, but it is certainly a strand of the DNA. Moreover, Moorer's voting rights argument, based on the Reconstruction Act of 1868 , comprises part of the lineage of the second Reconstruction and deserves that recognition. ${ }^{239}$

235 Darlene Clark Hine, Black Victory: The Rise and fall Of The White Primary In Texas (Columbia: U. Of Mo. Press 2003).

236321 U.S. 657 (1944).

237 HiNe, BLACK VICTORY at 249.

$238 / d$. at 17.

$239 / d$. at $17-18$. 